\title{
On Being an Angry Black Man
}

\section{Stephen John Quaye \\ Miami University}

U. S. A.

ABSTRACT: Black men are often seen as problems, threats, and thugs. The mere existence of a Black body is often met with fear. Using autoethnographic mystory, I blend personal stories, poetry, song lyrics, and analysis to subvert the angry Black man mantra and explore the productive use of anger to stimulate change.

KEYWORDS: Black, race, anger, autoethnography, mystory

Beginning: Mystories and Autoethnography

Living as a Contradiction

Michael Brown

Glorious Selma

Angry Enough to Practice Self-Care

Ending: Two Conclusions Plus One (Explicit) Note on Anger

References

Author Contact

\section{When Will It Stop?}

The rain patters on my windowsill

And I lie in bed restless, unable to sleep

My conscience goes to my heart

The quick pounding, sounding like the multiple hearts of all those hurting

When will it stop?

Not today, for the names keep coming

My tattoo reminds me to stay awake

Literally, in this moment I am awake

Awake to the sweat forming on my brow

Containing my spirit when it cannot be tamed

Pondering Sebastian, crushing his spirits

When he learns the world was not designed for him 
Nor me, nor...?

When will it stop?

Not tomorrow, for tomorrow will be many tomorrows

Mobilizing my anger, not pacifying the hopes of many

Senseless, emotionless, numbness

My body remains a problem

Not problems like things or worries or scars

But, the literal manifestation of who I am as a problem

A disturbance, a threat, an uneasiness

I scream to an empty silence

A silence of apathy, privilege, not hearing

When your voice shakes, you quiver

Because you know, it will not stop

And yet, you keep going, you work to heal

Your conscience, your mind, your heart

And the echoes of your past kin

Remind you stopping is not an option

Even when you know it will not stop

And yet, you still ask

When will it stop?

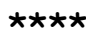

\section{Dear Sebastian,}

I'm angry. White police are killing too many Black people. Lately, you've been asking me about death. "What happens to people when they die, Daddy?" you ask in your innocent voice. "Well, they go to heaven." That response seems to pacify you...for now. I wrote the poem above shortly after Michael Brown's death. I was searching for the words to make sense of my feelings. And poetry was the best way to do that. I'm writing to you in words that I'm sure you won't quite understand, but as you grow older, I know you will, unfortunately, come to understand my words 
through how you are treated in the world as a person of color. No matter what others tell you, always know that I see you.

Love,

Daddy

\section{Beginning: Mystories and Autoethnography}

Academia privileges certain writing-using citations to support ideas, distancing one's personal self, and using empirical data to bolster claims (Matsuda \& Tardy, 2007). Although qualitative methods provide more liberty for transgressing these conventions, qualitative methods still favor more traditional notions of what counts as knowledge and who possesses knowledge (Richardson \& St. Pierre, 2008). To interrupt traditional norms, mystories combine personal narrative with scholarly discourse and popular culture (Magolda, 1999; Sabik, 1997; Ulmer, 1989). Writers using mystories blend facets of their lives that are often divorced (e.g., personal stories, music, art, poetry, scholarly discourse) to create holism between seemingly disparate selves and ideas. Mystories invite readers to step outside linear notions of writing and embrace discomfort to push boundaries and trouble commonly-held assumptions about life, writing, and meaning-making. Autoethnography foregrounds researchers' subjectivities and enables researchers to use personal stories to process larger cultural issues tied to power, privilege, and oppression (Ellis, 2004; Hancock, Allen, \& Lewis, 2015). I situate myself within a critical paradigm (Lincoln, Lynham, \& Guba, 2011), meaning I pay attention to history and power relations that oppress Black people. The blending of autoethnography, mystory, and my critical paradigm means I embrace a risk-taking, bold writing style that foregrounds my subjectivities in an effort to uproot racism.

The two goals of this paper are (a) to trouble anger as a negative emotion, and (b) to underscore ways faculty can enable students to see us as holistic beings with emotions and personal stories. Because Black students, in particular, are likely struggling with their own anger, modeling how we wrestle with anger as Black faculty members can mitigate power imbalances between professor and student and give students permission to express and process their own anger. In this autoethnographic mystory, I weave personal stories, poetry, scholarly discourse, and music lyrics to normalize anger and remove some stigma attached to anger.

I organize the paper into four sections illustrating key issues with which I am wrestling. First, I discuss living in my Black skin and the impact of Michael Brown's death on my life. Then, I use song lyrics to make sense of anger and racism. In the fourth section, I examine the importance of self-care and close with implications from my autoethnographic mystory. 


\section{Living as a Contradiction}

I am a Ghanaian/Black, heterosexual, cisgender man living in a middleclass environment. I am a parent of a multiracial child and a faculty member in a student affairs graduate program. I listen to an eclectic range of music. Kendrick Lamar's (2015) album To Pimp a Butterfly is one example. I have not found another artist who uses his voice to critique the senselessness of our time more deeply. From the way [White] capitalism works to entrench Black people in ghettos ("I'm trapped inside the ghetto, and I ain't proud to admit it I Institutionalized, I keep runnin' back for a visit"), to how White people use and abuse Black bodies ("You hate me, don't you? / You hate my people, your plan is to terminate my culture"), and to how Black self-hate works ("I mean, it's evident that I'm irrelevant to society / That's what you're telling me / Penitentiary would only hire me"), Lamar's music frees and heals me. And yet, as an advocate of social justice, I am a contradiction. I am a contradiction in endorsing Lamar's misogynistic lyrics while I critique how men treat Black women in our society as sex objects. I am a contradiction as I listen to lyrics that are often homophobic while I advocate for changing systems that allow queer people to live as their full selves. Yet, I still find inspiration in Lamar's music. Do I perpetuate the very problematic conditions I seek to dismantle? Yes/No, and yet, Yes. The poem below underscores this contradiction.

\section{Both/And}

"How can you experience joy if you are so angry?"

This is the question several of my White friends pose

My anger-it shines as bright as my cleanly-shaven bald head

"I'm worried about you, Stephen."

Are you?

Or, are you worried about your discomfort?

"I've seen a shift in you."

Have you?

Or, is how my Black body used to make you comfortable

now making you see my body as a source of disdain?

"Why are you so angry?"

Why aren't you angry?

For to live in fear is to be angry 
Never settled, always uneasy and on alert

I occupy a both/and space

The slash allows me to step in and out

To put on my bow tie during the day

And my hoodie at night

To smile at you

But cry inside

The slash means I can see the joy in my son

As I fear for his first realization of racism

Laugh with friends

But be tormented that they just don't get it

To be both/and means to resist either/or

Or, to sometimes occupy the either and the or

Or, to blend multiple eithers and ors

In Sister Citizen: Shame, Stereotypes, and Black Women in America, Melissa Harris-Perry (2011) centered the voices, stories, and experiences of Black women as they navigate harmful stereotypes to live as full citizens in a country that often misrecognizes them. In a Podcast called Intersection (2015), she wrestled with the notion of living as a contradiction; she vulnerably discussed how she often consumed sexist hip hop music. One might harshly judge HarrisPerry as undoing her position as a social justice advocate given the lyrics to which she listens. How can she possibly consume such harmful portrayals of women, while she points out the harm that stereotypes do to Black women as citizens? Her response to this potentially damning question: "I suspect there was a time when I tried to reconcile those things, and now I just see them as kind of separate.... I just choose to in fact ingest some pretty horrifying stuff at the same time as I see myself as an intersectional Black feminist" (Harris-Perry, 2015).

Some might interpret Harris-Perry's (2015) answer as a cop out, as a way to justify consuming damaging lyrics while still holding the mantle of "intersectional Black feminist." Key in Harris-Perry's comment is the word reconcile, which means "to restore friendly relations between" (Oxford Dictionaries, n.d.). That restoration is essentially what living as a contradiction means - to constantly restore relations, perhaps even unfriendly ones, between seemingly opposing positions. The inability of my friends referenced above to do this is essentially what fomented deeper anger and resentment toward them. They were unable to hold my anger and my pleasant demeanor, friendliness, and niceness in the same space. Anger can be an isolating feeling, and an even 
more excruciatingly isolating experience when one's community cannot embrace, handle, or live with one's anger. Lamar's music became my community; I listened to Lamar express anger freely and without reservation or apology. For example, in "The Blacker the Berry," he raps:

This plot is bigger than me, it's generational hatred

It's genocism, it's grimy, little justification

I'm African American, I'm African

I'm Black as the heart of a fuckin' Aryan

I'm black as the name of Tyrone and Darius

Excuse my French, but fuck you - no, fuck y'all

That's as blunt as it gets

I know you hate me, don't you? You hate my people

I can tell 'cause it's threats when I see you.

His music fueled my ability to live this contradiction, as uneasy as it made me feel at times. I work to model ways to do this for students.

\section{Michael Brown}

Living this contradiction has been especially important since 2014, as I have wrestled with many emotions as several cases of police brutality toward Black people have enveloped the news. I moved through anger, frustration, hopelessness, fear, and anxiety with occasional bouts of hope. Michael Brown, a Black teenager in Ferguson, Missouri, was killed by Darren Wilson, a White police officer on August 9, 2014. I was nearing the deadline to submit my promotion and tenure materials in August 2014, so I shut out my emotions and focused on my dossier. Following submission, I allowed myself to reflect on the questions swirling around in my head: What happened? How did this happen? What's the point of tenure in a world where my entire body is seen as a threat, a problem? I saw the hashtag, BlackLivesMatter, tweeted and retweeted across Twitter with a picture of Michael Brown. I listened to news anchors discuss his past. I sought to make sense of the distorted facts. Did he have a weapon? Did he charge at the police officer? Do these questions even matter?

\section{[Michael] Brown}

Brown v. Board of Education was supposed to give us access

But yet, brown is still a curse word, a problem

Because to be brown is to be the source of frown 
Brown-the antithesis of White

Not as bad as Black because that's how internalized oppression works

Pits Brown folks against Black folks

In a game of whose brown is the lightest and brightest?

Hues of all colors, yet brown is just plain

Plain but at the same time visible

Marked / scarred / bruised

"Son, remember you have to work twice as hard..."

I used to look at my browner-skinned sister and be grateful for my lighter brown

But, my youngest sister, her brown was the best, for it was the lightest

"Stop being a clown, don't you know you have to act right because you are brown?"

"Stop being, stop this, stop that..."

Always a limitation, something to be stopped

Not like the resistance of a conscious choice to stop

But, a passive act of stopping for you know your brown can get you in trouble

To be White-limitless possibilities, freedom, yes free-dom [freedom from dominance]

What do you do when your mind isn't yours?

You look at your brown skin and wish it away

You look at your white friends and crave their lack of brown

So used to wanting and yet all you want is to want lacking

You do your best to perfect your brownness

So, was Michael Brown just another brown victim?

Or, will his brown death mean something more than just forgotten brown, plain

So, if Michael Brown couldn't escape his brown, am I here by mere luck?

Or, is my brown just a brown safety net?

Destined to be browned into the ground

Like coffee grounds taken from brown lands

Hands up, don't shoot

Look at my palms, they are light like yours 
But, you pull the trigger because my brown is fear

Another brownie bites the dust

Forgotten, trampled on, not even covered

And yet, my brown is not as brown as Michael Brown's

But still brown just the same, plain

I became a runner the summer of 2015 . When I go running, I rarely see other Black people. Perhaps running was my final coronation into the land of Whiteness. Even though I sometimes post selfies with the hashtag \#BlackMenRun as an act of solidarity with other Black runners, running is still an isolating experience. And it is also freeing and empowering. Becoming a runner is fitting, as freeing and isolating (remember both/and?) constitute most of what I feel in life. On my first run in June 2015 , I could barely run five minutes without panting. I felt like quitting so many times those first few months. And even though I still don't like running, I have run three $5 \mathrm{Ks}$ and a $10 \mathrm{~K}$. So, perhaps it's okay to call myself a distance runner, with emphasis on the word distance.

For so much of my life, I distanced myself from Blackness. Outside of being born in Ghana and spending the first two and a half years of my life there, I have lived in predominantly White environments. I have learned how to live within those spaces. The few Black folks I interacted with often told me I acted White, mocked the way I talked and dressed and my mannerisms, and White people praised me for not being like other Black people. To cope, I distanced myself from Blackness. Distance runners travel far on their runs, distancing themselves from their starting position, which is sometimes their home. They often return to that starting position at the end of the run. Similarly, I learned to distance myself from my home, that is, my Blackness, in order to fit in within my White spaces.

Fictive kinship is a concept that underscores how people from minoritized communities find community, or kin, with unrelated people (Harris-Perry, 2011). This is why many Black people were so overjoyed when Barack Obama was elected president - we saw ourselves in him, even though most of us don't know him personally. Just as fictive kinship enables Black people to celebrate the successes of other unrelated Black people, their failures can also be crushing and make us feel shame in our Blackness. When I see a Black man in handcuffs, for example, I feel personal shame, sadness, and anger. I distanced myself from Blackness because the way I identified as a Black person differed from the stereotypes I saw about Black men (e.g., gangbangers, baggy pants and dorags, thugs, animalistic, scary). The problem is that by distancing myself from Blackness, I became rootless and couldn't find my way back home.

Michael Brown's death impacted me to my core because I saw myself reflected in him, and I saw my son reflected in him. I no longer distanced myself from Blackness but saw the realities of living while Black. Just as distance runners return to their home base or starting position, I knew that my Blackness 
was my home and that I needed to feel comfortable in my own skin, which is still a work in progress.

\section{Glorious Selma}

I saw the motion picture Selma on January 12, 2015, one week before Martin Luther King, Jr. Day. A poignant scene from the movie is the tension between King and SNCC members, the younger generation of activists. King advocated for a non-violent form of change, while SNCC members desired more radical activism. The tension I have painted oversimplifies a more nuanced approach supported by King and SNCC members. Nonetheless, this tension exists today, as [White] folks demonized protestors in Baltimore for looting and rioting while invoking King's non-violent mantra when convenient to their argument (Rector, Dance, \& Broadwater, 2015), often ignoring how social movements historically have contained radical, seemingly violent forms alongside peaceful, non-violent measures. The soundtrack to Selma contains a song, "Glory," by John Legend and Common, the inspiration for the next section. I use lyrics to highlight racial injustice, anger, and activism in today's society. I put quotation marks around the italicized lyrics to distinguish them from my own words, which are indented.

\section{Glory}

"One day, when the glory comes / It will be ours, it will be ours"

When will the glory come?

For some, their glory has come

The manifest destiny glory of taking ownership over a land

Is now the manifest destiny glory of taking ownership over a body

Black bodies set to perform, entertain, crack jokes, keep you laughing...so you forget the crying, the tears, the heartache, the destruction, our loneliness, our sighs, our regrets...

The manifest destiny glory of taking over a mind

The antithesis of stay awake but, instead, stay asleep

Nigger, nigga, whatever different spelling you want to use...nigger/nigga being thrown around like we created this word (ahem, did I say the manifest destiny of taking over a mind?)

"Oh, one day, when the war is won / We will be sure, we will be sure"

War 
"War, what is it good for? Absolutely, absolutely, nothing, nothing...."

The war on drugs. The war on crime. The war on welfare.

The war on our minds. The war on our bodies. The war on our selfesteem.

Oh wait...they won't tell you about those wars. We only wage wars on our enemies, and for United States society, the wars are always painted as outside the norm. There goes that pesky White supremacy and manifest destiny stuff again...

Oops, l'm letting my anger seep in...

"Hands to the heavens, no man, no weapon..."

If we have no weapons, why are they waging war on us, Daddy?

Hands up, don't shoot / I can't breathe

"Formed against us, yes glory is destined"

Not the manifest destiny glory I just said...but this glory is different. For this glory is about free-dom [freedom from dominance], about liberating our minds, our bodies, our souls. Racism ended, gone, poof...

"Everyday women and men become legends / Sins that go against our skin become blessings"

Sins-the sin of racism, the belief that just because I am darker-skinned, I am somehow less-than. How can these sins become blessings? I am an everyday man who doesn't consider myself a legend, and yet, when I use my voice, I turn those sins (you'll never amount to anything, you're just a thug, you're a threat) into blessings.

"Justice is juxtaposition in us / Justice for all just ain't specific enough / One son died, his spirit is revisitin' us / True and livin' livin' in us, resistance is us"

Justice is juxtaposition in us -- justice is just a position in us. If justice is just a position in us, then we all have justice within us, which means it is learned, and like anything learned, we have to unlearn some things, too...

If justice for all just ain't specific enough

Then \#AllLivesMatter just ain't specific enough

So, don't come back at me with \#AllLivesMatter when I'm telling you that \#BlackLivesMatter

Because this "all" that you speak of really subsumes difference and washes out the me in your all.

So, excuse me if I dismiss your all for one and one for all stance...just temporarily

Because I do pray for a day when justice for all is specific enough to include justice for Black and Brown folks. 
"That's why Rosa sat on the bus / That's why we walk through Ferguson with our hands up.

When it go down we woman and man up / They say, 'Stay down' and we stand up / Shots, we on the ground, the camera panned up / King pointed to the mountaintop and we ran up.

One day, when the glory comes / It will be ours, it will be ours / Oh, one day, when the war is won / We will be sure, we will be sure / Oh, glory, glory / Oh, glory, glory, glory"

\author{
War \\ When will the war be won? \\ When will the glory be ours? \\ When will Black folks have anything to call ours? \\ Despite oppression and racism \\ We created, we invented \\ Musical genres to represent our stories \\ Art to reflect our existence \\ Writing to demonstrate our perseverance \\ Sports to exude our prowess \\ And now they co-opt \\ Take our glory and manifest it as their own \\ Culturally appropriate our music \\ Consume our art \\ Erase and E-race it \\ So that it is more culturally acceptable \\ More reflective of their own stories \\ And yet, we search for our glory \\ We fight for the one day \\ When our glory is our glory
}

"Now the war is not over / Victory ain't won / And we'll fight on to the finish / Then when it's all done / We'll cry glory, oh glory / We'll cry glory, oh glory" 


\section{Victory \\ How is victory possible?}

When the very society is based on some groups attaining victory

and all others losing

I don't want to fight to the finish

For the finish means all else has ended

But yet, I do want our glory

To not just say glory but to cry and shout it

Victory isn't possible

When our society is based on exclusion

So, while I wait to cry glory

I cry from pain, hurt, frustration, unattained hopes and dreams

I cry from stolen stories, stolen childhoods, stolen dreams

I cry from crying too much and too long

I cry from not experiencing joy when so many are dying

I cry from the apathy around me

I cry from not seeing who I am reflected

And, ultimately, I cry because my patience is wearing thin

"Selma's now for every man, woman, and child / Even Jesus got his crown in front of a crowd"

I knocked on doors, I told people why they should vote for then Senator Obama. I donated money. I proudly told my friends and family why Obama deserved my vote. So, on November 4, 2008, when I watched him get elected as the first African American President of the United States, I had never felt more proud to be living in this country. And then so quickly after he got elected, the articles came pouring in about how we are now living in a post-racial society, and Obama's election demonstrates that we have transcended race as a nation. So, it's no wonder that so many young people have trouble seeing how "Selma's now." And yet, Michael Brown's death, among so many others, as well as overt and subtle forms of racism illustrate that we are far from a post-racial, post-Selma society. So, if Selma is now, then that means we must, now, continue the work toward justice. 
"They marched with the torch, we gon' run with it now / Never look back, we done gone hundreds of miles / From dark roads he rose, to become a hero / Facin' the league of justice, his power was the people"

The Mobilizing Anger Collective (MAC) is a group of faculty, staff, students, and community members who gather to build solidarity and challenge acts of injustice on Miami University's campus and the surrounding Oxford community. In Fall 2014, following Michael Brown's death, two Black colleagues and I met to process our anger. From this initial meeting, we developed the MAC. Since 2014, we have held a townhall meeting, open mic nights, and a silent protest, to name a few.

The Mobilizing Anger Collective

A healing space for my anger

Allowing my anger to persist

Mobilizing it to promote change

Or, sitting in it and not being critiqued for it

My people

Who see me, are me, and love me

For the me that is me in a world that the me is confined

So, ask me what it feels like to be labeled as a problem

"Enemy is lethal, a king became regal / Saw the face of Jim Crow under a bald eagle / The biggest weapon is to stay peaceful"

\section{Oppression and Freedom}

How do these two polar opposite actions exist in the same country?

We use the bald eagle as a symbol of our independence, freedom, strength and resolve as a nation

A nation where people who looked like me were $60 \%$ or three fifths of a person

A fraction, a percentage

Used to classify people, human beings

How is the possible?

We see the bald eagle, next to our beautiful American flag

And yet, not all Americans can vote 
Participate equally in this free-dom country

And yet, King asked us to stay peaceful

Imagine the patience of Black people

We are asked to keep our emotions subdued

Stand silently while White folks spit on us

Curse at us, demonize us, beat us, abuse us

Stay peaceful

In the midst of torment, torture, taunts

Can a weapon that is inherently based on a lack of emotion really be a weapon?

And yet Black folks remained peaceful

Even as they stayed awake

When we are not peaceful our lack of peace is demonized

Rioters, looters, thugs, disturbers of the peace is what we are labeled

But, at a certain point, how can there be peace?

What is peace when only a piece of you is seen?

And when that piece of you is seen as threatening, how can you be at peace?

What is peace when only a piece of you is seen?

What is peace when only a piece of you is seen?

Holism is what we crave

To have our many pieces be seen as whole / Then there is peace

To be treated as full members / Then there is peace

To be greater than the sum of our parts / Then there is peace

But until then, we protest

We stop demonizing anger and violence

For sometimes, they are the only weapons we have

So our hearts and our spirits can be at peace

Even when they are in pieces

"We sing, our music is the cuts that we bleed through

Somewhere in the dream we had an epiphany

Now we right the wrongs in history

No one can win the war individually 
It takes the wisdom of the elders and young people's energy

Welcome to the story we call victory

The comin' of the Lord, my eyes have seen the glory"

Too often, older generations demonize young people for their naiveté and unbridled passion for imagining a different kind of world. And this criticism often comes from people who also hold minoritized identities. Meanwhile, the system of oppression remains intact because people with minoritized identities are pitted against each other. And yet, we need both voicesthe "wisdom of the elders and young people's energy"-to address racism on multiple levels.

\section{Angry Enough to Practice Self-Care}

In her TED Talk, The Danger of a Single Story, Chimamanda Ngozi Adichie (2009) cites Poet Mourid Barghouti, who said: "If you want to dispossess a people, the simplest way to do it is to tell their story and to start with secondly" (para, 24). Start the story with Black people as looters, rioters, thugs, and criminals and not with the history of White supremacy and slavery and racism in United States society, and you have an entirely different story. "If you want to dispossess a people, the simplest way to do it is to tell their story and to start with secondly."

\section{Secondly}

To have secondly, you must have first

And to have first, you must have secondly

Thirdly comes next

Just like third-world countries follow the first-world country

But, what countries are second-world?

If secondly sits in between first and third

Then, why do you always start my story with secondly?

Because to ignore the first

Means you refuse to see the first

For the first is just a given

The standard to which the secondly and the third and the last are measured

But, the third might as well be the last

Since that is how you see my Ghanaian country 
But, what if you allowed me to tell my story

To start with first

In my own words

From my own voice

From my own footsteps

From the rice and peanut butter soup that fills my grumbling tummy

To the loud Ghanaian music that fills an empty living room

From the plantains that I like best fried

To the accents that remind me of home

From the okra stew that I used to turn my nostrils up at

To the kente cloth that is proudly strewn across my body

No more secondlys

Or, third world madness

Just first, beginning, commencing

Like the commencement of the end of an academic year

To begin anew, in our own stories and voices

Not the secondly from some other mouths

That don't have our accents or stories

I'm seeing a therapist. Finally. There, I said it. I have a Ph.D. I am an associate professor. I have a kind, curious child. According to White standards of success, I have made it. I am Black, and I have made it in White America. So, why the hell do I need a counselor? I am at times painstakingly self-aware. I reflect often. I am deliberate, intentional, focused. So, why the hell do I need a counselor? What can a counselor possibly tell me about myself that I don't already know? I don't need help. After all, I've made it in White America. I've succeeded for 36 years, so why the hell do I need a counselor?

\section{Answer: Because of Secondly}

For 36 years, I have viewed my life as secondly. My former [White] partner was first. My son is first. My students are first. My needs are secondly. How can I prioritize my needs when Black people are dying? I have made it in White America. My life isn't as hard. I have privilege [read: I am not worthy of taking care of myself; I don't have time for that]. And then it started. I hadn't written 
much since leaving the University of Maryland in 2012. I blamed it on fatigue. I blamed it on being a parent. I said I needed a break. And while all of that was true, the real reason was I was anxious. I was/am a perfectionist (as an aside, I now call myself a recovering perfectionist). I was so overwhelmed with racism, with my Blackness, with my internalized oppression that I did not see myself as worthy of taking care of me. And I did not trust counselors. I did not want to talk about racism and have it be explained away, for someone to tell me I was being too sensitive or overreacting. When I met with students, and I determined that what they needed was beyond the scope of what I could provide, without reservation, I suggested they see a counselor, stigma removed. Yet, I had been socialized to try to pray harder when struggling. So, what changed? Why did I decide to see a counselor at this point in my life?

\section{Further Answer: Because of Secondly}

I became angry. So angry that I had allowed White voices to tell me that I was not worthy of taking care of myself. So angry that my life was falling apart - I had lost my confidence as a parent. I was parenting from a place of fear and avoiding meltdowns. So, l'd acquiesce, rather than face another meltdown. Also, I couldn't write. Finally, rather than social media serving as a virtual community for me, it was fueling my despair. I couldn't support my students because I was too engrossed in my own struggles. I was tired of being dispossessed, so dispossessed that I was not practicing self-care. I had started to believe that I was a problem. I could not love like I wanted to because I was not taking care of myself. So, with my privileges, I accessed counseling. And with my counselor's help, I am learning to challenge the secondly in me, to be angry enough to practice self-care as my act of resistance.

\section{Ending: Two Conclusions Plus One (Explicit) Note on Anger}

I close with two larger conclusions that readers can draw from my autoethnographic mystory and a final comment about anger. First, stories matter. We work to eradicate racism when we take time to listen to stories from those with whom we believe we have little in common. Stories challenge assumptions, dispel myths, and foster empathy. Stories matter for others, but equally as important, they matter for the story-teller. Writing and sharing my stories has enabled me to begin healing and process the complexities of racism and my anger.

Next, combating racism means acknowledging individual oppression and systemic oppression. Although stories matter, on their own, they are insufficient for dismantling racism. Stories must be tied with systemic oppression. Racism is perpetuated not just because individual White people do racist things, but also 
because racism is embedded in policies, laws, and values that appear normal and natural.

Finally, anger is necessary. A central theme of anger is embedded in this autoethnographic mystory. As a Black person, I have been socialized not to let my anger out, for fear of making White people afraid and showing too much emotion. Labeling myself as "an angry Black man" is an act of resistance resistance toward norms of how Black men should be. This label is also an act of healing - trying to make peace in a world that denies so much of my humanity. These two acts - resistance and healing - have enabled me to survive in White America, experience joy and pain simultaneously, move through the palpable fear as I drive by police officers, and see my body as not a problem.

Those wishing to support Black people in our anger must first and foremost validate us when we show anger. Educators must also encourage us to express anger and normalize it as a necessary emotion. Validation seems so easy, and yet so many people in my world have struggled to validate consistently. When I and other Black people express our anger, we are told to calm down, stop overreacting, and manage our emotions before we can be heard. As such, we have learned to internalize our anger as abnormal and damaging. If anger from Black people makes you uncomfortable, pause, and reflect on what it is within you that is causing the discomfort rather than blaming Black people for their anger or telling them to calm down.

My journey as a faculty member/parent consists of using my voice, my words, and my anger to stimulate change in order to reclaim my angry Black man identity and move it from fear to a place of sustenance. Through this autoethnographic mystory, I long to be seen and for others to see themselves through my words. So, sit with me, feel my anger, reflect on your own stories, and ultimately, just be.

\section{References}

Adichie, C. N. (2009). The danger of a single story [Video transcript]. Retrieved from TED Website: https://www.ted.com/talks/chimamanda_adichie_the_ danger_of_a_single_story/transcript?language $=e n$

Bochner, A. P. (2001). Narrative's virtues. Qualitative Inquiry, 7, 131-157.

Ellis, C. (2004). The ethnographic I: A methodological novel about autoethnography. Walnut Creek, CA: AltaMira Press.

Hancock, S., Allen, A., Lewis, C. W. (2015). Autoethnography as a lighthouse: Illuminating race, research, and the politics of schooling. Charlotte, NC: Information Age Publishing.

Harris-Perry, M. V. (2011). Sister citizen: Shame, stereotypes, and Black women in America. New Haven, CT: Yale University Press. 
Harris-Perry, M. V. (Speaker), \& Smith, J. (Producer). (2015, December 1). Being Melissa Harris-Perry is a full-time job [Audio podcast]. Retrieved from https://newrepublic.com/article/124739/intersection-episode-10-melissaharris-perry-full-time-job

Lamar, K. (2015). To pimp a butterfly. Hollywood, CA: Chalice Recording Studios.

Legend, J., \& Common. (2014). Glory. On Selma (CD). New York, NY: Columbia Records.

Lincoln, Y. S., Lynham, S. A., \& Guba, E. (2011). Paradigmatic controversies, contradictions, and emerging confluences, revisited. In N. K. Denzin \& Y. S. Lincoln (Eds.), The Sage handbook of qualitative research (pp. 97-128). Thousand Oaks, CA: Sage.

Magolda, P. M. (1999). Mystories about alternative discourses in a qualitative inquiry seminar. Qualitative Inquiry, 5(2), 208-243.

Matsuda, P. K., \& Tardy, C. M. (2007). Voice in academic writing: The rhetorical construction of author identity in blind manuscript review. English for Specific Purposes, 26(2), 235-249.

Oxford Dictionaries. (n.d.). Definition of reconcile in English. Retrieved from http://www.oxforddictionaries.com/us/definition/american_english/reconcile

Rector, K., Dance, S., \& Broadwater, L. (2015, April 28). Riots erupt: Baltimore descends into chaos, violence, looting. The Baltimore Sun. Retrieved from http://www.baltimoresun.com/news/maryland/freddie-gray/bs-md-ci-policestudent-violence-20150427-story.html

Richardson, L., \& St. Pierre, E. A. (2005). Writing: A method of inquiry. In N. K. Denzin \& Y. S. Lincoln (Eds.), The Sage handbook of qualitative research (pp. 959-978). Thousand Oaks, CA: Sage.

Sabik, C. A. M. (1997). (Re)writing metaphor and form: Autoethnographic enactments from the postmodern classroom. Unpublished doctoral dissertation, Cleveland State University, Cleveland, $\mathrm{OH}$.

Ulmer, G. L. (1989). Teletheory: Grammatology in the age of video. New York, NY: Routledge.

Winfey, O., Colson, C., Gardner, D., \& Kleiner, J. (Producers), \& DuVernay, A. (Director). (2014). Selma (Motion picture). United States: Paramount Pictures.

\section{Author Contact}

Stephen John Quaye / quayesj@miamioh.edu

Miami University: 210 East Spring Street, Oxford, OH 45056, USA 